\title{
Effect of Using Oil Cooler Trainer Module on the Competence of Heat Transfer at the Universitas Negeri Surabaya
}

\author{
I Made Arsana* \\ Department of Mechanical Engineering \\ Universitas Negeri Surabaya \\ Surabaya, Indonesia \\ madearsana@unesa.ac.id \\ Rachmad Syarifudin Hidayatullah \\ Department of Mechanical Engineering \\ Universitas Negeri Surabaya \\ Surabaya, Indonesia \\ rachmadhidayatullah@unesa.ac.id
}

\author{
Soeryanto \\ Department of Mechanical Engineering \\ Universitas Negeri Surabaya \\ Surabaya, Indonesia \\ soeryanto@unesa.ac.id \\ Agysta Yoso Apriliasari \\ Automotive Light Vehicle Engineering \\ SMK 45 Surabaya \\ Surabaya, Indonesia \\ agystayosoapriliasari@gmail.com
}

\author{
Sudirman Rizki Ariyanto \\ Automotive Technology Vocational Education \\ Universitas Bhinneka PGRI Tulungagung \\ Tulungagung, Indonesia \\ sudirman@stkippgritulungagung.ac.id
}

\begin{abstract}
The purpose of this research is to determine the differences in student learning outcomes before and after the application of the oil cooler trainer learning module in heat transfer courses. This study is an experimental study with the one group pretest-posttest experimental design to determine differences in student learning outcomes before and after the application of the oil cooler trainer module. The application of learning with the oil cooler trainer module was carried out for D3 students of DA2 class Mechanical Engineering Faculty of Engineering UNESA, as many as 15 students who took heat transfer courses in the even semester. The experimental design used was The One Group Pretest-Posttest with data analysis techniques used were quantitative descriptive methods. The results showed that this learning module can be used in learning heat transfer courses in UNESA Mechanical Engineering. This is indicated by the results of paired sample t-test analysis showed that there were differences in the learning outcomes of D3 students in the DA2 Mechanical Engineering UNESA class between before and after the application of the oil cooler trainer learning module in the heat transfer course with the acquisition of a tcount of -19.899 located outside the table range between 2.14479 and -2.14479 .
\end{abstract}

Keywords: oil cooler trainer, module, t-test, heat transfer courses, higher education

\section{INTRODUCTION}

Education is one of the efforts that has an important role in improving the quality of human resources and is the responsibility of all parties, both government, society, and educational institutions. Indonesia is a developing country that continues to strive to fulfill the rights of every citizen in obtaining education. This is in accordance with the definitions contained in Law Number 20 Year 2003 concerning the National Education System. In line with that, to ensure the implementation of quality education the government sets National Education Standards (NES) in Government Regulation No. 19 of 2005 concerning National Education Standards [1].

Surabaya State University as one of the educational institutions in Indonesia also supports the implementation of quality education by producing educators for quality pre-school education, basic education and secondary education [2]. The Department of Mechanical Engineering is one of the departments that has three study programs namely S1 in Mechanical Engineering Education, S1 in Mechanical Engineering and D3 in Mechanical Engineering [3]. In each study program there are several compulsory courses that must be taken by all students.

Heat Transfer is one of the compulsory subjects that must be taken by all students. Heat transfer is classified into thermal 
conductivity [4], thermal convection, thermal radiation and heat transfer through phase changes [5]. There are facilities and infrastructure that are used to support the learning process in order to meet predetermined curriculum demands. The heat transfer laboratory as an infrastructure that supports the learning process has several learning facilities in the form of trainers that are used as learning media so that students more easily capture and understand heat transfer material delivered by the teaching lecturer [6]. Oil cooler trainer is one of the trainers owned by the heat transfer laboratory which is used as a learning medium to understand the process of forced thermal convection.

This oil cooler trainer has not yet been equipped with a learning module, so students still have difficulty in understanding the material presented by the teaching lecturer. How to teach that is still conventional is also an obstacle for students in understanding learning material. In addition, based on curriculum studies that have been carried out, it can be seen that in the syllabus of heat transfer courses there is no practicum, whereas if practicum activities are applied in the process of teaching and learning activities can spur student creativity [7]. This can be proven from the achievement of the final value of the D3 Mechanical Engineering heat transfer course student year 2012/2013, 2013/2014 and 2014/2015.

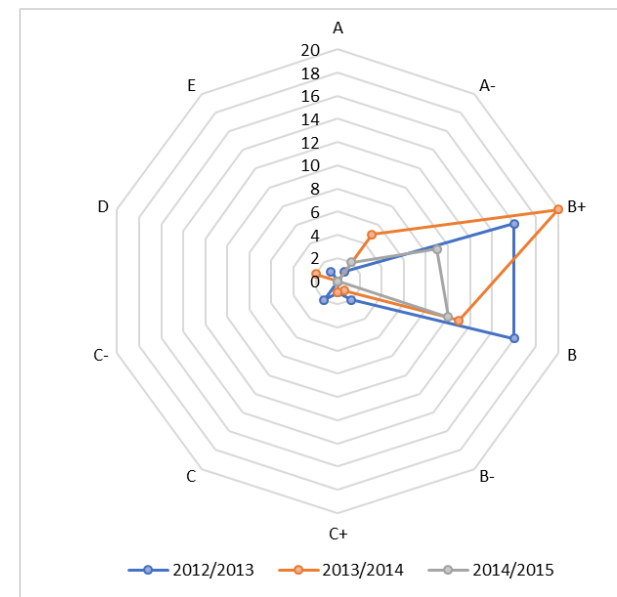

Fig. 1. Radar diagram of the value of the heat transfer course for the 2012/2013, 2013/2014 and 2014/2015 academic years.

Source: Unesa Mechanical Engineering Department (2016) [8]

Based on the table of D3 students' mechanical transfer courses in UNESA Academic Year 2012/2013, 2013/2014 and 2014/2015 above, it can be concluded that students are still unable to achieve maximum learning outcomes, this is evidenced by the acquisition of $\mathrm{A}$ grades that has a percentage of $0 \%$. Referring to these problems, the researchers applied learning with modules to determine differences in student learning outcomes before and after the application of the oil cooler trainer module. The success of using learning modules can of course be measured based on the results of previous research. Huda \& Arsana (2013) developed a thermal radiation learning module equipped with a media trainer. The result shows that the module is declared valid with good category. Besides, the completeness of student learning outcomes also indicates the achievement of learning completeness up to
$100 \%$. Meanwhile, it is known that the student's response to the use of the thermal radiation learning module gets a good response [9].

Arifiansyah \& Arsana (2014) applies module-based LCD Projector learning media. The results of this study indicate an increase in student learning outcomes of $78.12 \%$ in cycle I and $87.05 \%$ in cycle II. The learning outcomes fall into the "Very Good" category [10]. Devi \& Arsana (2015) developed a wire and tube heat exchanger trainer free convection module. The results concluded that the development of a module with a 4-D model greatly assisted students in improving learning outcomes and understanding of the material of wire-free convection and heat exchanger tube heat courses [11].

The learning device that will be applied is an oil cooler trainer module, with this learning module expected to facilitate students in understanding heat transfer material delivered by the teaching lecturer so as to obtain maximum learning results. In addition, this oil cooler trainer module can be used to equip students on the basics of heat transfer so that they can support competencies, especially in the automotive engineering field. This is what underlies the researchers raised a study entitled "The Effect of the Oil Cooler Trainer Module on the Competence of Heat Transfer at the Universitas Negeri Surabaya".

\section{RESEARCH METHOD}

\section{A. Research Design}

This study has aimed to knowing the differences in student learning outcomes before and after the application of the oil cooler trainer learning module in heat transfer courses. The method in this study used The One Group Pretest-Posttest Design, as shown in Table 1 [12].

TABLE I. RESEARCH DESIGN

\begin{tabular}{|c|c|c|}
\hline $\mathrm{O}_{1}$ & $\mathrm{X}$ & $\mathrm{O}_{2}$ \\
\hline Pretest & Treatment & Posttest \\
\hline
\end{tabular}

Information:

$\mathrm{O}_{1}$ : Test before treatment (treatment) with the application of learning with the oil cooler trainer module.

$\mathrm{X}$ : Treatment given to D3 students of Mechanical Engineering UNESA, namely the application of learning with the oil cooler trainer module.

$\mathrm{O}_{2}$ : Test after the treatment (treatment) the application of learning with the oil cooler trainer module

\section{B. Research Instruments}

The test is a way of getting a score that reflects student learning outcomes. In this study, the tests used were pre-test and post-test. The pre-test is used to measure the extent to which students' abilities and initial understanding of the material to be taught. At the same time, the post-test is used to measure student learning outcomes by applying the oil cooler trainer module. The learning outcomes in this study consist of affective, cognitive, and psychomotor domains. Affective assessment in this study uses two aspects of attitude assessment, namely religious attitudes and social attitudes [13]. 
Then, cognitive assessment uses an assessment instrument in the form of tests, namely formative tests at each learning activity and evaluation tests at the end of learning [3].

The formative test aims to determine the level of understanding of students in receiving the material presented by the lecturer in each learning activity, while the evaluation test seeks to determine the level of student understanding of the entire material that has been delivered by the lecturer [14] Meanwhile, psychomotor assessment uses test assessment instruments in the form of practicum reports and assessment instruments in the form of observations or observations of practical work steps [15].

\section{Data Analysis Technique}

The normality test is used to test whether the samples taken come from populations that are normally distributed. In this study, data from each variable was examined for normality [16]. To make it easier, the normality test is carried out based on the Kolmogorov-Smirnov test using the SPSS 18 software [17]. Before analyzing using the t-test, it is necessary to formulate a hypothesis. The hypothesis of this study is as follows.

Ho: $\mu 1=\mu 2$ : There is no difference in learning outcomes between before and after the application of the Oil Cooler Trainer Module in the Heat Transfer Course.

Ha: $\mu 1 \neq \mu 2$ : There are differences in learning outcomes between before and after the application of the Oil Cooler Trainer Module in the Heat Transfer Course.

The analysis used to test the first hypothesis of this study is Paired-sample t-Test. Paired-sample t-Test is used to compare the average of two variables in one group, namely to test one sample that gets a treatment which will then be compared to the average of the sample between before and after treatment.

\section{RESULTS AND DISCUSSION}

In this development research, a learning module called the Oil Cooler Trainer Module was produced to support the heat transfer course at Surabaya State University. The research results were in the form of description of data obtained in the field related to the Oil Cooler Trainer Module itself. It aims to provide a general overview of the assessment of student learning outcomes of the Oil Cooler Trainer Module. The data analyzed in this research development are in the form of student learning outcomes data. The data taken is used as a benchmark for the Oil Cooler Trainer Module as a learning medium in the heat transfer course at Surabaya State University.

\section{A. Data of Learning Outcome}

Student learning outcomes are obtained from the results of student tests conducted before all material is delivered (PreTest) and after all material is delivered (Post-Test), the test is given to students of D3 class DA2 in Mechanical Engineering UNESA. The learning outcomes of D3 class DA2 students in
Mechanical Engineering UNESA can be described in the table below.

TABLE II. PRE-Test AND Post-Test LeARNing Outcomes

\begin{tabular}{|c|c|c|c|}
\hline No & Student ID & Pre-Test & Post-Test \\
\hline 1 & 033 & 50 & 92.92 \\
\hline 2 & 035 & 55 & 93.71 \\
\hline 3 & 036 & 50 & 94.61 \\
\hline 4 & 038 & 47.5 & 93.97 \\
\hline 5 & 039 & 50 & 86.86 \\
\hline 6 & 040 & 35 & 83.97 \\
\hline 7 & 042 & 52.5 & 85.46 \\
\hline 8 & 043 & 55 & 85.96 \\
\hline 9 & 044 & 45 & 90.75 \\
\hline 10 & 045 & 50 & 88.36 \\
\hline 11 & 047 & 37.5 & 85.85 \\
\hline 12 & 048 & 60 & 88.6 \\
\hline 13 & 049 & 52.5 & 85.2 \\
\hline 14 & 050 & 52.5 & 79.01 \\
\hline 15 & 051 & 52.5 & 85.07 \\
\hline \multicolumn{2}{|r|}{ Total } & 745 & 1320 \\
\hline \multicolumn{2}{|r|}{ Average } & 49.7 & 88.02 \\
\hline
\end{tabular}

Based on Table 2, the learning outcomes of UNESA DA2 mechanical engineering diploma students can be described as shown in Figure 2.

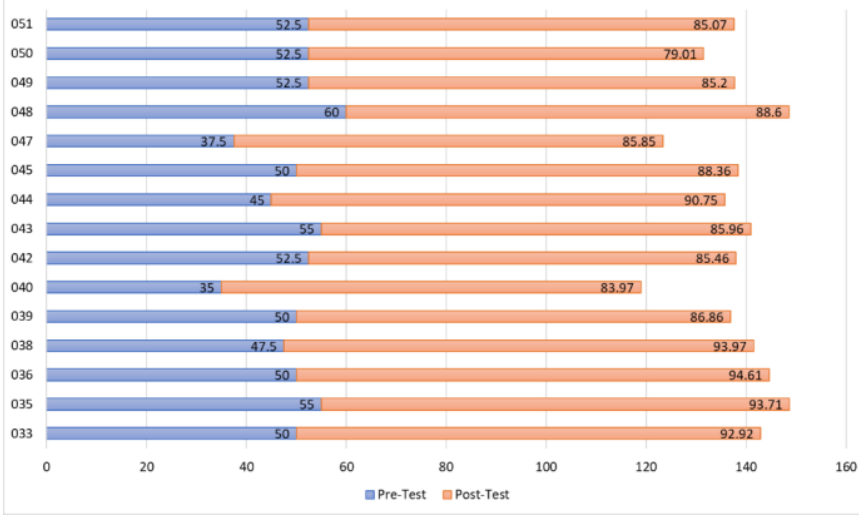

Fig. 2. iagram of pre-test and post-test learning outcomes

Based on the bar diagram in Figure 2, it is stated that the average value of the pre-test obtained by diploma students in the DA2 class of Mechanical Engineering UNESA is still said to be low, namely by obtaining a pre-test value of 49.7. The average post-test value of diploma students of DA2 Mechanical Engineering UNESA class is 88.02, so it can be concluded that the average value of the final pre-test and post-test of diploma students of DA2 Mechanical Engineering UNESA class there is an increase in learning outcomes before and after application Oil Cooler Trainer learning module in heat transfer courses. 


\section{B. The Hypothesis Test of Learning Outcomes}

The analysis used to test the hypotheses of learning outcomes is Paired-sample t-Test. Paired-sample t-Test is used to compare the average of two variables in one group, namely to test one sample that gets a treatment which will then be compared the average of the sample between before and after treatment [18]. The results of the Paired-sample t-Test analysis using SPSS are as follows.

TABLE III. ANALysis RESUlt OF FIRST PAIRED-SAMPLE T-TeST

\begin{tabular}{|c|l|c|c|c|c|}
\hline & Test & Mean & N & $\begin{array}{c}\text { Std. } \\
\text { Deviation }\end{array}$ & $\begin{array}{c}\text { Std. Error } \\
\text { Mean }\end{array}$ \\
\hline Pair 1 & Pre-Test & 49.67 & 15 & 6.469 & 1.670 \\
\hline & Post-Test & 88.02 & 15 & 4.426 & 1.143 \\
\hline
\end{tabular}

The table above shows a summary of the two samples. For pre-test, students have an average score of 49.67 out of a total of 15 students. While the post-test scores, students have an average value of 88.02 from a total of 15 students. In addition, the table also shows the standard deviation and standard error mean of each variable.

TABLE IV. Analysis Result of SeCond PaIRED-SAmple T-Test

\begin{tabular}{|c|c|c|c|c|c|c|c|c|}
\hline \multicolumn{2}{|c|}{ Test } & Mean & $\begin{array}{c}\text { Std. } \\
\text { Deviation }\end{array}$ & $\begin{array}{c}\text { Std. Error } \\
\text { mean }\end{array}$ & $\begin{array}{c}\text { 95\% Confidence } \\
\text { interval of the } \\
\text { difference }\end{array}$ & t & df & $\begin{array}{c}\text { Sig. } \\
\text { (2-tailed) }\end{array}$ \\
\cline { 4 - 7 } & & & & Lower & Upper & & & .000 \\
\hline Pre-test \& Post-test & -38.353 & 7.465 & 1.927 & -42.487 & -34.219 & - & 14 & 19.899
\end{tabular}

Decision-making:

Based on the comparison of $t_{\text {coun }} t$ with $t_{\text {table }}$ :

- If $t_{\text {count }}$ is in the $t_{\text {table }}$ range, then Ho is accepted and Ha is rejected.

- If the $t_{\text {count }}$ is outside the $t_{\text {table }}$ range, then Ho is rejected and Ha is accepted.

$\mathrm{t}_{\text {count }}$ of the output is $-19,889$

table $=\mathrm{t}(0.05 / 2 ; 15-1)=\mathrm{t}(0.025 ; 14)=2.14479$

Because $t_{\text {count }}$ is equal to $-19,889$ which is outside the $t_{\text {table }}$ range, which is between 2.14479 and -2.14479 , H0 is rejected and $\mathrm{Ha}$ is accepted, ie there are differences in student learning outcomes between before and after the application of the Oil Cooler Trainer learning module in the heat transfer course.

\section{Discussion}

Based on the analysis of the D3 student DA2 Mechanical Engineering UNESA student learning outcomes data with the application of the Oil Cooler Trainer learning module in the heat transfer course stated that the minimum post-test value obtained by D3 students of the Mechanical Engineering class UNESA was 79.01 and the maximum post-test value obtained by D3 students of Mechanical Engineering DA2 class of 94.61. The average post-test value of D3 students in the DA2 class of Mechanical Engineering UNESA was 88, so it can be concluded that the average post-test value of D3 students in the DA2 class of Mechanical Engineering UNESA was higher than the average pre-test value of 49, 7. Hypothesis testing using the t-test Paired-sample t-Test on the pre-test and post-test values obtained by students then obtained $t_{\text {count }}=-19,899$, this value is outside the range of $t_{\text {table }}$, ie between 2.14479 and -2.14479 then $\mathrm{H} 0$ rejected, so Ha was accepted who said that there were differences in student learning outcomes between before and after the application of the Oil Cooler Trainer learning module in the heat transfer course.

\section{CONCLUSIONS}

Student learning outcomes in the application of the oil cooler trainer learning module in the heat transfer course have differences between before and after the application of the oil cooler trainer learning module in the heat transfer course. This is shown from the average pre-test value of D3 students in the DA2 Mechanical Engineering UNESA class of 49.7 and the average post-test value of D3 students in the DA2 Mechanical Engineering UNESA class of 88.02, so it can be concluded that the average value The post-test of D3 students in DA2 Mechanical Engineering UNESA class is higher than the average pre-test. Compared sample t-test t-test of the pre-test and post-test values obtained by students of D3 class DA2 in Mechanical Engineering UNESA then obtained t-count = 19,899 , this value is outside the range of table that is between 2.14479 and -2.14479 then HO is rejected and Ha is accepted, so it can be concluded that there are differences in student learning outcomes between before and after the application of the oil cooler trainer learning module in heat transfer courses. Therefore, the oil cooler trainer learning module can be used by lecturers in improving student learning outcomes in learning heat transfer courses in UNESA mechanical engineering.

\section{REFERENCES}

[1] Republik Indonesia, Peraturan Pemerintah No. 19 Tahun 2005 tentang Standar Nasional Pendidikan. Indonesia, 2005, pp. 1-42.

[2] I. M. Arsana, I. W. Susila, R. S. Hidayatullah, and S. R. Ariyanto, "Implementation of Troubleshooting Teaching Method to Develop Student's Competency in Conducting Motorcycle Tune-up," 2019, doi: 10.1088/1742-6596/1387/1/012096.

[3] I. M. Arsana, S. R. Ariyanto, and H. G. Wibisono, "Implementation of Problem-Based Learning Models Supported by Trainer Radiator Module for Heat Transfer Learning," J. Taman Vokasi, vol. 7, no. 2, pp. 226-231, 2019.

[4] A. Gufron and I. M. Arsana, "Rancang Bangun Alat Penambal Ban dengan Pengontrol Suhu Otomatis," J. Rekayasa Mesin, vol. 04, no. 02 , pp. 39-46, 2017. 
[5] I. M. Arsana, Susianto, K. Budhikarjono, and A. Altway, "Optimization of the single staggered wire and tube heat exchanger," MATEC Web Conf., vol. 58, no. August, p. 01017, 2016, doi: 10.1051/matecconf/20165801017.

[6] S. R. Ariyanto and I. M. Arsana, "Pengembangan Modul Radiator Trainer sebagai Penunjang Mata Kuliah Perpindahan Panas Mahasiswa D-III Teknik Mesin Universitas Negeri Surabaya," J. Pendidik. Tek. Mesin, vol. 05, no. 01, pp. 28-33, 2016.

[7] H. G. Wibisono and I. M. Arsana, "Penerapan Modul Radiator Trainer Berbasis Pendekatan Scientific Learning untuk Meningkatkan Aktivitas Belajar pada Mata Kuliah Perpindahan Panas Mahasiswa S1 Teknik Mesin B Unesa,” J. Pendidik. Tek. Mesin, vol. 05, no. 02, pp. 119-123, 2016.

[8] Unesa Mechanical Engineering Department, "Learning Outcomes of Heat Transfer Courses Unesa Mechanical Engineering Department Students." Unesa Mechanical Engineering Department, Surabaya, 2016.

[9] M. Huda and I. Arsana, "Pengembangan Modul Pembelajaran Thermal Radiation Untuk Menunjang Perkuliahan Perpindahan Panas Mahasiswa D3 Teknik Mesin Ft Unesa," J. Pendidik. Tek. Mesin, vol. 2, no. 01, pp. 15-23, 2013.

[10] Y. S. Arifiansyah and I. M. Arsana, "Meningkatkan Kompetensi Keselamatan Dan Kesehatan Kerja Siswa Kelas X TKR 1 di SMK 01 YP 17 Lumajang," J. Pendidik. Tek. Mesin, vol. 2, no. 3, pp. 18-25, 2014.

[11] N. K. A. R. L. Devi and I. M. Arsana, "Pengembangan Modul Pembelajaran Wire and Tube Heat Excahanger Trainer Untuk Menunjang Perkuliahan Perpindahan Panas Mahasiswa S1 Pendidikan Teknik Mesin Unesa," J. Pendidik. Tek. Mesin, vol. 4, no. 2, pp. 29-36,
2015, doi: 10.1017/CBO9781107415324.004.

[12] J. W. Creswell, Research design: Qualitative, quantitative and mixed approaches (3rd Edition), 3rd ed. Los Angeles: SAGE Publications, Inc., 2009.

[13] S. R. Ariyanto, M. Munoto, and M. Muhaji, "Development of affective authentic assessment instruments for automotive engineering expertise in vocational school," J. Taman Vokasi, vol. 7, no. 1, p. 42, Jul. 2019, doi: 10.30738/jtv.v7i1.4777.

[14] Soeryanto, I. M. Arsana, R. S. Hidayatullah, and S. R. Ariyanto, "Analysis of HOTS Type Multiple-choice Test Items on Learning Automotive Electrical Systems in SMK Dharma Bahari Surabaya," J. Phys. Conf. Ser., vol. 1569, p. 032046, Jul. 2020, doi: 10.1088/17426596/1569/3/032046.

[15] S. R. Ariyanto, M. Munoto, and M. Muhaji, "Development of Psychomotor Domain Assessment Instrument on Brake System Competence in SMKN 1 Jetis Mojokerto," Int. J. Educ. Vocat. Stud., vol. 1, no. 6, Aug. 2019, doi: 10.29103/ijevs.v1i6.1648.

[16] P. Mishra, C. Pandey, U. Singh, A. Gupta, C. Sahu, and A. Keshri, "Descriptive statistics and normality tests for statistical data," Ann. Card. Anaesth., vol. 22, no. 1, p. 67, 2019, doi: 10.4103/aca.ACA_157_18.

[17] Z. Drezner, O. Turel, and D. Zerom, "A modified kolmogorov-smirnov test for normality," Commun. Stat. Simul. Comput., vol. 39, no. 4, pp. 693-704, 2010, doi: 10.1080/03610911003615816.

[18] N. Sanaie, P. Vasli, L. Sedighi, and B. Sadeghi, "Comparing the effect of lecture and Jigsaw teaching strategies on the nursing students' selfregulated learning and academic motivation: A quasi-experimental study," Nurse Educ. Today, vol. 79, pp. 35-40, Aug. 2019, doi: 10.1016/j.nedt.2019.05.022. 